\title{
Konflikt międzynarodowych, unijnych i krajowych interpretacji prawa podatkowego lub celnego (próba „hierarchizacji” interpretacji)
}

\section{Kwestie terminologiczne}

Wzrost znaczenia różnorodnych form interpretacji prawa, a w szczególności prawa podatkowego i celnego, jest zjawiskiem nie do powstrzymania. Obywatele oczekują stabilności i jasności prawa. Realne możliwości uproszczenia prawa podatkowego i celnego są z różnych względów ograniczone ${ }^{1}$. Rozwój interpretacji prawa staje się substytutem uproszczenia prawa. Prawo nie staje się klarowniejsze, ale jednostka może w interpretacji znaleźć rozwiązanie nurtujących ją pytań o sposób jego rozumienia, a poza tym interpretacja może zapewniać jednostce ochronę, nawet gdyby była niezgodna z prawem.

Rozwój interpretacji polega nie tylko na tym, że jednostka coraz częściej uzyskuje interpretację i korzysta z niej. Następuje także różnicowanie form działalności interpretacyjnej, istnieją nie tylko interpretacje indywidualne i ogólne, lecz także interpretacje, które można określić jako wyspecjalizowane, czyli dotyczące tylko jednego problemu prawnego ${ }^{2}$. Poza tym wzrasta liczba podmiotów, które taką działalność prowadzą. Interpretacje wydawane są nie tylko przez krajowe organy podatkowe i celne. Efektem globalizacji jest to, że akty interpretacyjne

* Dr Wojciech Morawski - Katedra Prawa Finansów Publicznych, Wydział Prawa i Administracji, Uniwersytet Mikołaja Kopernika w Toruniu.

${ }^{1}$ Por. na ten temat m.in.: S. D. Pollack, Tax Complexity, reform, and the illusions of tax simplification, „George Mason Independent Law Review” 1994, nr 2; B. Brzeziński, O idei uproszczenia prawa podatkowego, [w:] T. Dębowska-Romanowska, A. Jankiewicz (red.), Konstytucja, ustrój, system finansowy państwa. Księga pamiątkowa ku czci prof. Natalii Gajl, Warszawa 1999; B. Brzeziński, Uproszczenie podatków i prawa podatkowego, [w:] B. Brzeziński (red.), Prawo podatkowe. Teoria. Instytucje. Funkcjonowanie, Torun 2009; J. Prebble, Can Incom Tax be Simplified?, „New Zealand Journal of Taxation Law and Policy" 1996, nr 2; C. Pau, A. Sawyer, A. Maples, Complexity of New Zealand's tax law: An empirical study, „Australian Tax Forum” 2007, nr 22.

2 Przykładem może być reskrypt uzyskiwany we Francji w celu uniknięcia zarzutu nadużycia prawa (abus de droit) (art. L 64 LPF). 
wydają także organizacje międzynarodowe. Aktywną działalność w dziedzinie prawa celnego prowadzi Światowa Organizacja Celna (WCO) ${ }^{3}$. Efektem działalności interpretacyjnej WCO jest m.in. znaczna liczba not wyjaśniających i opinii klasyfikacyjnych dotyczących klasyfikacji taryfowej towarów (w zakresie HS). Za swoistą interpretację prawa można także uznać Komentarz do Modelu Konwencji OECD. Także organy UE prowadzą aktywną działalność interpretacyjną. Jej efekty - np. wytyczne Komisji - stanowią część tzw. soft law ${ }^{4}$.

W niniejszym opracowaniu przyjęto szeroki sposób rozumienia pojęcia „,interpretacja prawa” jako każdej formy aktywności organu władzy publicznej lub organizacji międzynarodowej, ukierunkowanej na dokonanie wykładni prawa, o ile nie odbywa się ona w toku stosowania prawa.

Wzrost liczby form interpretacji, wydawanych dodatkowo przez różne podmioty, paradoksalnie powoduje jednak skomplikowanie sytuacji jednostki - musi ona poznać kolejne (poza przepisami prawa) materiały, które - z uwagi na ich ilość i zróżnicowanie podmiotów je wydających - nie muszą być ze sobą spójne. W sytuacji braku spójności interpretacji rodzi się naturalne pytanie: która z interpretacji jest „ważniejsza”? Dokonanie hierarchizacji interpretacji „porządkuje” sytuację prawną jednostki.

Hierarchizacja interpretacji może następować na dwóch płaszczyznach: obowiązywania (walidacyjnej) oraz wykładni samych interpretacji. Pierwszy przypadek rozwiązania konfliktu interpretacji polega na pozbawieniu znaczenia prawnego interpretacji stojącej hierarchicznie niżej. Skutek ten może następować automatycznie, bez konieczności wydawania jakiegokolwiek aktu administracyjnego. Jednak analogiczne zastosowanie do interpretacji zasady, iż akt prawny stojący hierarchicznie wyżej uchyla akt niższego rzędu nie jest jedynym rozwiązaniem. Istnienie jednej interpretacji może tyko wymuszać podjęcie przez „organ interpretacyjny" ${ }^{5}$ działań zmierzających do ujednolicenia treści interpretacji poprzez dostosowanie treści interpretacji stojącej hierarchicznie niżej do tej uznawanej za dominującą - przy czym, w przeciwieństwie do konfliktu norm prawnych, konflikt interpretacji wcale nie musi być rozstrzygnięty, o ile interpretacje nie są wiążące. W efekcie hierarchizacja interpretacji wcale nie musi być tak jednoznaczna jak ta dotycząca przepisów prawnych.

Za dość zbliżone rozwiązanie można uznać takie, gdy interpretacja stojąca hierarchicznie niżej może zachować swoją moc prawną, ale jednostka nie będzie mogła się na nią powołać w celu uniknięcia konieczności zapłacenia podatku lub cła ${ }^{6}$.

${ }^{3}$ Powołana jako Rada Współpracy Celnej (RWC) na mocy Konwencji o utworzeniu Rady Współpracy Celnej, sporządzonej w Brukseli dnia 15 grudnia 1950 r. (Dz. U. z 1978 r. Nr 11, poz. 43).

${ }^{4}$ D. Sarmiento, The Function of EU Soft Law, [w:] D. Weber (red.), Traditional and Alternative Routes to European Integration, Amsterdam 2010, s. 55.

${ }^{5}$ Może nim być organ władzy publicznej lub organ organizacji międzynarodowej.

${ }^{6} \mathrm{~Np}$. handlowiec korzystający z interpretacji wydanej na mocy art. 11 rozporządzenia Rady (EWG) nr 2913/92 z dnia 12 października 1992 r. ustanawiającego Wspólnotowy Kodeks Celny 
Hierarchizacja nie musi mieć tylko charakteru walidacyjnego, ale może mieć postać dyrektywy wykładni. Na przykład w zakresie klasyfikacji taryfowej towarów noty wyjaśniające Komisji traktowane są jako uzupełnienie not WCO i powinny być tak interpretowane, aby były zgodne z tymi ostatnimi ${ }^{7}$. W tym wypadku także widać odmienności między hierarchizacją przepisów prawnych a hierarchizacją interpretacji, która nie jest tak „ostra”.

Przedmiotem niniejszego opracowania będzie próba odpowiedzi na pytanie, czy i w jakim stopniu doszło do hierarchizacji interpretacji prawa podatkowego i celnego oraz jakie kryteria decydują o jej kształcie. Trzeba zastrzec, że przedmiotem badań będzie jedynie próba hierarchizacji różnych form interpretacji, zostanie więc pominięta kwestia konfliktu interpretacji tego samego typu, np. sprzeczności interpretacji wcześniejszej i późniejszej.

\section{Czy prymat prawa unijnego ma charakter bezwzględny?}

Nie budzi wątpliwości to, że prawo krajowe musi być zgodne z regulacją unijną. W efekcie $\mathrm{w}$ pewnych sytuacjach podatnik może powołać się na prawo unijne, które nie zostało implementowane do krajowego porządku prawnego ${ }^{8}$. Naturalne jest pytanie, czy można $\mathrm{z}$ tego wywieść zasadę, że zawsze interpretacja unijna będzie miała prymat nad interpretacją krajową i ewentualnie na czym miałyby polegać skutki tegoż prymatu.

Żywą dyskusję we Francji budzi w ostatnich latach kwestia znaczenia tzw. „doktryny podatkowej”9 sprzecznej z prawem unijnym. Spór dotyczy tego, czy podatnik może powołać się na doktrynę administracyjną sprzeczną z prawem unijnym. W wyroku Cour administrative d'appel (CAA) w Paryżu z dnia 17 grudnia $1991 \mathrm{r}^{10}$ dopuszczono możliwość powołania się przez podatnika nawet na sprzeczną z prawem unijnym interpretację. W późniejszym wyroku CAA w Douai z dnia 26 kwietnia 2005 r. zaprezentowano pogląd odmienny ${ }^{11}$. Uzasadnieniem dla niego miałaby być zasada prymatu prawa unijnego w relacji do prawa

(Dz. Urz. UE L 302 z 19 października 1992 r. ze zm.) (dalej: w.k.c.) nie będzie mógł skorzystać z ochrony wynikającej z art. 220 ust. 2 lit. b w.k.c., gdy mógł wykryć błąd organu. Istnienie innej interpretacji może być uznane za okoliczność ułatwiającą wykrycie błędu organu celnego.

${ }^{7}$ Wyrok TS z dnia 4 października 1979 r. w sprawie J. Cleton $v s$. Inspecteur der invoerrechten en accijzen Rotterdam, 11/79, ECR (1979), s. 3069. Wynika to aktualnie już z samej preambuły do not wyjaśniających Komisji.

${ }^{8}$ C. Mik, Europejskie prawo wspólnotowe, Warszawa 2000, s. 294.

9 Można ją w pewnym uproszczeniu utożsamiać z pojęciem interpretacji prawa podatkowego.

${ }_{10}$ Wyrok CAA w Paryżu z dnia 17 grudnia 1991 r., nr 357, Restauration Gestio, RJF 1992, nr 2, s. 232.

${ }^{11}$ Wyrok CAA w Douai z dnia 26 kwietnia z 2005 r., nr 02DA00736, Segafredo Zanetti France, RJF 2005, nr 36, s. 1175. 
krajowego. W późniejszym wyroku CAA w Paryżu z dnia 25 marca 2010 r. ${ }^{12}$ sąd ten podtrzymał swój wcześniejszy pogląd dotyczący możliwości powoływania się na interpretacje nawet sprzeczne z prawem unijnym. W doktrynie wydają się dominować poglądy zgodne ze stanowiskiem sądu w Paryżu ${ }^{13}$. Wskazuje się m.in. na to, że gwarancja ta jest zgodna z zasadami ogólnymi prawa unijnego, jak zasada ochrony uzasadnionych oczekiwań ${ }^{14}$. Prawodawca unijny wprost zgadza się $\mathrm{z}$ tym, aby nawet wiążąca informacja taryfowa sprzeczna z prawem unijnym nadal chroniła jej posiadacza nawet 6 miesięcy po jej uchyleniu ${ }^{15}$. Nie można więc dokonywać swoistej „absolutyzacji” zasady prymatu prawa unijnego. Poza tym prawo do powołania się na prawo unijne w sytuacji braku implementacji do krajowego porządku prawnego przysługuje - i to w pewnych sytuacjach - tylko jednostce, nie zaś państwu, które naruszyło swoje obowiązki.

W powyższych wyrokach nie chodziło wprost o konflikt między interpretacjami krajowymi a interpretacjami unijnymi, lecz o sytuację, gdy interpretacja krajowa była albo ewidentnie sprzeczna z prawem unijnym, albo ową sprzeczność można było domniemywać, gdyż była ona sprzeczna z wyrokiem TS UE. Tak samo można jednak domniemywać, że interpretacja unijna jest zgodna z prawem unijnym.

Tym bardziej jednak brakuje podstaw do sformułowania poglądu, że krajowa interpretacja prawa podatkowego sprzeczna $\mathrm{z}$ interpretacją unijną (np. wytycznymi Komitetu VAT opublikowanymi jako: A Selection of Guidelines Agrees by the VAT Committee from 1977 to 2010 (as at 31 December 2010) with regard to questions concerning the application of EU VAT provisions $)^{16}$ tylko $\mathrm{z}$ tego powodu nie chroniłaby podmiotu działającego w zaufaniu do niej. Wytyczne Komitetu VAT nie mają charakteru wiążącego. Krajowe organy podatkowe powinny się do nich stosować, nawet gdy nie wynika to wyraźnie z art. 14a i 14e $\S 1$ o.p., ale reakcją na stwierdzenie sprzeczności interpretacji krajowej z wytycznymi może być tylko zmiana interpretacji w trybie przewidzianym przez Ordynację podatkową i z zachowaniem wszelkich mechanizmów ochrony interesów jednostki.

12 Wyrok CAA w Paryżu z dnia 25 marca z 2010 r., nr 08PA03658, SARL A la Fregate, „Revue du droit fiscal" 2010, nr 36, s. 55.

${ }_{13}$ F. Goguel, La garantie contre le changement de doctrine face au droit communaitaire, „Droit fiscal” 2006, nr 21-22, poz. 1026 i n.; M. Guichard, R. Grau, La doctrine administrative contraire au droit de l'UE est opposable. Note, „Revue du droit fiscal” 2010, nr 36, s. 57-60.

${ }^{14}$ S. Gouès, La doctrine administrative contraire au droit de l'UE est opposable. Conclusion, „Revue du droit fiscal” 2010, nr 36, s. 55.

${ }^{15}$ Art. 12 ust. 6 w.k.c.

$16 \mathrm{http} / / /$ ec.europa.eu/taxation_customs/resources/documents/taxation/vat/key_documents/ vat_committee/guidelines_en.pdf. Dokument dostępny jest tylko w języku angielskim. Guidelines będą tłumaczone w niniejszym opracowaniu jako „wytyczne”, aczkolwiek można je traktować jako swoiste interpretacje ogólne (gdyby analogicznie odnosić tu terminologię Ordynacji podatkowej). 


\section{Interpretacje międzynarodowe a interpretacje krajowe}

Ordynacja podatkowa nie reguluje w wyraźny sposób konfliktu między interpretacjami wydanymi na podstawie art. 14a o.p. a takimi interpretacjami, jak Komentarz OECD czy porozumienia zawierane (w polskich realiach dość rzadko) w ramach procedury wzajemnego porozumiewania się na podstawie umów o unikaniu podwójnego opodatkowania ${ }^{17}$.

Charakter prawny porozumień MAP aktualnie budzi kontrowersje. Brak wyraźnej podstawy prawnej związania organów krajowych porozumieniem MAP nie jest specyfiką czy niedoskonałością polskiej regulacji prawnej. Wskazywano, że przyjęcie wiążącego charakteru takiego porozumienia $\mathrm{w}$ stosunku do sądu nie budziłoby oporów w Szwecji ${ }^{18}$, jednak już sądy w USA nie czują się związane tymi porozumieniami ${ }^{19}$. W samym Komentarzu OECD wskazuje się, że w wypadku, gdy już trwa spór sądowy, implementacja porozumienia MAP może być warunkowana zgodą podatnika i wycofaniem skargi z sądu ${ }^{20}$. Jednak w stosunku do organów podatkowych porozumienie MAP miałoby być, zdaniem Komentarza OECD, wiążące ${ }^{21}$. Kwestia wiążącego charakteru porozumień MAP wydaje się pochodną zasad konstytucyjnych danego państwa, a przede wszystkim tego, w jakim zakresie zawieranie porozumień międzynarodowych poddane jest kontroli parlamentu ${ }^{22}$.

Jeżeli zostanie zawarte porozumienie sprzeczne $\mathrm{z}$ interpretacją wydaną na podstawie Ordynacji podatkowej, to w świetle polskiego prawa jedyną drogą „,uzgodnienia” ich treści jest zmiana tej ostatniej interpretacji. Nawet gdyby istniało mniej korzystne niż interpretacja porozumienie MAP, to podatnik będzie mógł - do czasu jej zmiany - powołać się skutecznie na interpretację. Może to spowodować powstanie podwójnego nieopodatkowania, jeżeli z porozumienia MAP wynika, że to Polska ma prawo opodatkować dany dochód, a interpretacja prezentuje pogląd odmienny.

Można postrzegać to jako pewną niekonsekwencję, skoro na podstawie art. $240 \S 1$ pkt 10 o.p. należy wznowić postępowanie zakończone decyzją

17 Dalej: porozumienie MAP.

18 J. F. A. Jones, Ch. J. Berg, H.-R. Depret, M. J. Ellis, P. Fontaneau, R. Lenz, T. Miyatake, S. I. Roberts, C. Sandels, J. Strobl, D. A. Ward, The Legal Nature of the Mutuale Agreement Procedure Under OECD Model Convention - I, „British Tax Review” 1980, no. 1, s. 348 i n.

19 Patrz wyroki w sprawie Xerox 1994 r. czy w sprawie The Snak-on Tools Inc. z 1992 r.; cyt. za: J. A. Becerra, Interpretation and Application of Tax Treaties in North America, Amsterdam 2007, s. 75-80.

20 Pkt 31 Komentarza OECD do art. 25 ust. 2; patrz też: H. Hamaekers, [w:] H. Hamaekers, K. Holmes, J. Głuchowski, T. Kardach, W. Nykiel, Wprowadzenie do międzynarodowego prawa podatkowego, Warszawa 2006, s. 150.

${ }^{21}$ Pkt 36 Komentarza OECD do art. 25 ust. 3 dotyczącego rozwiązywania ogólnych problemów interpretacyjnych.

${ }^{22}$ M. Lehner, [w:] Klaus Vogel on Double Taxation Conventions, Londyn 1997, s. 1379. 
ostateczną, gdyby wynik zakończonej procedury wzajemnego porozumiewania się miał wpływ na jej treść. Przepis ten nie znajduje zastosowania do interpretacji prawa podatkowego ${ }^{23}$, w efekcie powstaje wrażenie, jakby interpretacja była bardziej „stabilna” niż decyzja. Ciekawie wygląda sytuacja, gdy organ podatkowy wydał decyzję zgodną z interpretacją korzystną dla podatnika, a następnie zostało zawarte porozumienie dla podatnika niekorzystne. Organ musi wznowić postępowanie podatkowe, ale na wniosek podatnika będzie musiał uwzględnić zwolnienie podatkowe wynikające $\mathrm{z}$ faktu korzystania przez niego $\mathrm{z}$ interpretacji ${ }^{24}$. Dopiero wskutek zmiany interpretacji w trybie art. 14e o.p. porozumienie zawarte w ramach MAP wywrze realny skutek na gruncie polskiego systemu podatkowego.

Analogicznie przepisy polskiego prawa podatkowego milczą na temat waloru prawnego Komentarza OECD do Modelu Konwencji. Pojawiające się niekiedy w literaturze zagranicznej poglądy, jakoby Komentarz OECD miał charakter wiążący $^{25}$ trudno zaakceptować ${ }^{26}$. Nie istnieją więc podstawy prawne do formułowania tezy o istnieniu „sztywnej” relacji hierarchicznej między interpretacjami krajowymi a Komentarzem OECD. W praktyce wydawania interpretacji indywidualnych prawa podatkowego nie jest mi jednak znany przypadek wydania takiej, w której wprost odrzucono by pogląd zawarty w Komentarzu OECD ${ }^{27}$. Z praktycznego punktu widzenia można więc mówić o pewnym stosunku hierarchizacji między Komentarzem OECD a interpretacjami, ale tylko na płaszczyźnie wykładni prawa. Hierarchizacja polega na tym, że organ interpretacyjny będzie preferował wykładnię prawa zgodną z Komentarzem OECD. Rozwiązanie takie należy uznać za ze wszech miar uzasadnione, m.in. zasadą dobrej wiary obowiązującą przy stosowaniu umowy międzynarodowej, jak i względami praktycznymi, nakazującymi preferować taką wykładnię umowy, która może zostać zaakceptowana przez drugie państwo-stronę umowy.

Na podstawie powyższych obserwacji nie można sformułować tezy o prymacie interpretacji międzynarodowych w relacji do interpretacji krajowych prawa podatkowego na płaszczyźnie ich obowiązywania (walidacyjnej). Jednak w praktyce interpretacje międzynarodowe wpływają na treść interpretacji krajowych; w tym aspekcie można mówić o jakimś stopniu ich hierarchizacji.

\footnotetext{
${ }^{23}$ A contrario art. $14 \mathrm{~h} \S 1$ o.p.

${ }^{24}$ Art. $14 \mathrm{~m}$ o.p.

${ }^{25} \mathrm{~Np}$. F. Engelen, Some Observations on the Legal Status of the Commentaries of the OECD Model, „Bulletin for International Taxation” 2006, March, s. 105-109.

${ }^{26}$ Patrz np. D. Ward, The Role of the Commentaries on the OECD Model in the Tax Treaty Interpretation Process, „Bulletin for International Taxation” 2006, no. 3, s. 99; M. Erasmus-Koen, S. Douma, Legal Status of the OECD Commentaries - In Search of the Holy Grail of International Tax Law, „Bulletin for International Taxation” 2007, no. 8, s. 346; W. Morawski, Interpretacje prawa podatkowego i celnego - stabilność i zmiana, Warszawa 2012, s. 115 i n.

${ }_{27}$ Także pracownicy Ministerstwa Finansów zajmujący się problematyką umów międzynarodowych sceptycznie podchodzą do takiej ewentualności. Pomijam sytuacje, gdy organ wydaje interpretację sprzeczną z Komentarzem OECD, ale nie wiąże się to ze sformułowaniem krytycznej oceny treści Komentarza, a jest przykładowo wynikiem wadliwego rozumienia jego treści.
} 
Konflikt międzynarodowych, unijnych i krajowych interpretacji prawa podatkowego... 407

Odmienne podejście prezentuje prawodawca unijny na gruncie prawa celnego w zakresie wiążących informacji taryfowych wydawanych przez krajowe organy celne. Tracą one moc wskutek powstania sprzeczności z późniejszą notą lub opinią $\mathrm{WCO}^{28}$.

\section{Interpretacje unijne a międzynarodowe}

Zwrot ,interpretacje unijne” rozumiem tu jako obejmujący interpretacje wydawane przez organy unijne. Przypadki konfliktu takich interpretacji występują jedynie na gruncie prawa celnego i są nieliczne. Z praktycznego punktu widzenia problem ten ma znaczenie w zakresie klasyfikacji taryfowej towarów, gdzie - jak już powyżej wskazano - noty wyjaśniające Komisji traktowane są jako uzupełnienie not WCO i powinny być tak interpretowane, aby były zgodne z tymi ostatnimi.

Rozwiązanie takie można też postrzegać jako refleks zasady, że Unia Europejska, tak samo jak każde państwo uczestniczące w międzynarodowym ładzie prawnym, przestrzega prawa międzynarodowego. Wynika z tego pośrednio, że działania podejmowane przez organy państw tworzących Unię powinny być zgodne z prawem międzynarodowym. Noty i opinie WCO można postrzegać jako swoisty dowód właściwego sposobu rozumienia tego prawa.

\section{Interpretacje wiążące a niewiążące}

Prima facie naturalnym kryterium hierarchizacji mógłby być charakter prawny interpretacji. Interpretacje wiążące dla organu skarbowego stałyby w takim wypadku hierarchicznie wyżej. Na gruncie polskiego prawa podatkowego problem ten nie istnieje, gdyż - przynajmniej formalnie - żaden z rodzajów interpretacji wydawanych przez polskie organy podatkowe (na podstawie Ordynacji podatkowej) albo przez nie stosowanych (jak Komentarz OECD) nie ma charakteru wiążącego ${ }^{29}$.

Wiążące interpretacje występują na gruncie prawa celnego. Jednak we Wspólnotowym Kodeksie Celnym prawodawca przyjął zupełnie odmienne rozwiązanie. Noty i opinie WCO oraz noty Komisji, mimo że są ważnym instrumentem wykładni prawa celnego, to nie są wiążące ani dla organu, ani dla jednostki ${ }^{30}$,

${ }^{28}$ Art. 12 ust. 5 lit. a pkt ii) w.k.c.

${ }^{29}$ Wyrok TK z 11 maja 2004 r., K 4/03 poważnie ogranicza możliwość nadania interpretacjom (zwłaszcza ogólnym) charakteru wiążącego.

${ }^{30}$ Wyrok TS z dnia 19 listopada 1975 r. w sprawie Douaneagent der NV Nederlandse Spoorwegen $v s$. Inspecteur der invoerrechten en accijnzen, C-38/75, ECR (1975), s. 01439. 
lecz powodują utratę ważności WIT ${ }^{31}$, która ma charakter wiążący dla organów celnych. Prawodawca przyjął więc inne niż charakter prawny kryterium hierarchizacji.

W literaturze wskazuje się niejednokrotnie na wątpliwości co do sensu przyjętego rozwiązania, zgodnie z którym akt niewiążący powodowałby automatyczną utratę mocy aktu wiążącego ${ }^{32}$. Z okoliczności niewiążącego charakteru not i opinii WCO oraz not Komisji wyciąga się niekiedy daleko idące wnioski, zmierzające do odrzucenia automatyzmu utraty ważności WIT. Wskazuje się mianowicie, że z uwagi na brak wiążącego charakteru not i opinii WCO oraz możliwość, że są one błędne, organy celne powinny ostrożnie podchodzić do stwierdzania utraty ważności WIT ${ }^{33}$, a nawet uznaje się, że utrata ważności WIT z powodu wadliwej noty lub opinii powinna być anulowana ${ }^{34}$. Pogląd taki jest jednak ewidentnie sprzeczny z art. 12 ust. 5 lit. a zdanie drugie w.k.c. Wynika z niego jasno, że datą utraty ważności WIT jest w wypadku wydania opinii lub zmiany not WCO data opublikowania komunikatu Komisji w serii C Dziennika Urzędowego Unii Europejskiej. Nie istnieje tryb ,przywracania mocy” WIT, które w ten automatyczny sposób utraciły ważność wraz z opublikowaniem not Komisji lub informacji o wydaniu not i opinii $\mathrm{WCO}^{35}$. Poza tym rozwiązanie przyjęte w w.k.c. zdaje się mieć pewne zalety ${ }^{36}$.

\section{Interpretacje ogólne a indywidualne}

W polskim prawie podatkowym brakuje regulacji dotyczącej konfliktu treści interpretacji ogólnej i indywidualnej. W efekcie wydanie interpretacji ogólnej innej treści niż wydawana uprzednio interpretacja indywidualna nie powoduje utraty ważności interpretacji indywidualnej. Tak samo organ interpretacyjny wydający interpretację indywidualną - przynajmniej teoretycznie - nie jest związany interpretacją ogólną i może wydać interpretację indywidualną o odmiennej treści. Usunięcie sprzeczności między treścią interpretacji indywidualnej a ogólnej

${ }^{31}$ Art. 12 ust. 5 lit. a pkt ii) w.k.c.

32 B. J. M. Terra, Community Customs Law, Haga-Londyn 1995, s. 80; D. Rovetta, P. D. Gavier, BTI: Advance Tariff Classification Ruling in the EC, „Global Trade and Customs Journal” 2009, vol. 4, issue 6, s. 177.

${ }^{33}$ D. Rovetta, P. D. Gavier, op. cit., s. 177.

${ }^{34}$ Ibidem.

${ }^{35}$ Szerzej: W. Morawski, Wią̇ące i niewiążace interpretacje prawa celnego - jak bardzo wiażace, jak bardzo niewiążace, [w:] T. Nowak, P. Stanisławiszyn (red.), Regulacje w zakresie prawa celnego i podatku akcyzowego po przystapieniu do Unii Europejskiej-polskie doświadczenia i perspektywy, Opole 2011, s. 332-351.

${ }^{36}$ Patrz pkt 6 niniejszego opracowania. 
może polegać tylko na usunięciu z obrotu prawnego jednej z nich ${ }^{37}$. Organ nie ma jednak takiego obowiązku, w efekcie w obrocie prawnym mogą istnieć dwie interpretacje (indywidualna i ogólna) sprzeczne ze sobą. Podatnikowi przysługuje prawo wyboru, do której interpretacji się zastosuje ${ }^{38}$. Można więc stwierdzić brak stosunku hierarchicznego między interpretacjami indywidualnymi a ogólnymi wydawanymi na podstawie Ordynacji podatkowej.

Zupełnie odmiennie wygląda sytuacja, gdy chodzi o interpretacje dotyczące klasyfikacji taryfowej w prawie celnym. Przyczyną utraty ważności WIT jest powstanie niezgodności z przyjętą przez inne podmioty, niż organ wydający WIT, interpretacją nomenklatury taryfowej ${ }^{39}$. Interpretacje, których pojawienie się powoduje utratę ważności WIT to te, które w terminologii polskiego prawa podatkowego można byłoby określić jako ,interpretacje ogólne”. Są to, po pierwsze, różnorodne interpretacje wydawane przez WCO, po drugie, interpretacje organów unijnych (chodzi tu o wydanie lub zmianę not wyjaśniających do CN, które wydaje Komisja ${ }^{40}$. Powyższa regulacja nie powoduje, że nigdy nie dojdzie do sprzeczności między notą Komisji lub WCO a WIT. Tylko bowiem nota lub opinia wydana po wydaniu WIT spowoduje utratę jej ważności ${ }^{41}$. Wiążąca informacja taryfowa sprzeczna z notami lub opiniami już w momencie wydania utraci ważność dopiero wskutek cofnięcia lub zmiany przez organ celny, który ją wydał.

Powyższa regulacja pozwala stwierdzić, że (z pewnymi wyjątkami związanymi z relacją czasową pomiędzy wydaniem noty lub opinii a wydaniem WIT) noty i opinie WCO oraz noty Komisji (akty niewiążące) można uznać za stojące hierarchicznie wyżej niż wiążące informacje taryfowe.

Rodzi się oczywiste pytanie: dlaczego akty „mocniejsze” (wiążące) muszą ustąpić pola aktom „słabszym” (niewiążącym)? Można tu wskazać na argumenty przemawiające za racjonalnością przyjęcia takiego rozwiązania. Przede wszystkim nota lub opinia WCO ma charakter ,powszechny”. Może się na nią powoływać każdy, a więc jej zasięg oddziaływania jest większy niż zasięg WIT. Wynika z tego pośrednio to, że nota lub opinia WCO oraz nota Komisji mają poważny potencjał w zakresie ujednolicania praktyki stosowania taryfy. Jeżeli prawodawca chce dokonać ujednolicenia praktyki stosowania taryfy, to logiczne jest, że daje prymat instrumentom ,powszechnym” nad indywidualnymi.

37 Przykładowo, w interpretacji z dnia 22 czerwca 2010 r. (DD2/033/132/PMN/10/453) minister finansów, uzasadniając zmianę interpretacji indywidualnej (pierwotnie interpretacja była dla podatnika niekorzystna), powołał się na utrwaloną (korzystną dla podatników) linię orzeczniczą i okoliczność, że „Minister Finansów, uwzględniając orzecznictwo sądów, wydał w dniu 15 lutego 2010 r. interpretację ogólną Nr DD2/033/259/PMN/09/1113".

${ }_{38}$ W. Morawski, Interpretacje prawa podatkowego i celnego..., s. 337.

${ }^{39}$ Art. 12 ust. 5 lit. a pkt ii w.k.c. Identyczny skutek wywołuje wydanie przez TS orzeczenia sprzecznego z wydaną wcześniej WIT.

${ }^{40}$ Są one publikowane w Dzienniku Urzędowym Unii Europejskiej serii C.

${ }^{41}$ Postanowienie TS z dnia 19 stycznia 2005 r. w sprawie Commissioners of Customs \& Excise vs. SmithKline Beecham plc, C-206/03 ECR [2005], s. I-415. 
Hierarchizacja, która wiąże się z automatyczną utratą mocy interpretacji indywidualnej wskutek sprzeczności z interpretacją ogólną, wydaje się dogodnym narzędziem realizacji zasady równości. Mankamentem interpretacji indywidualnych jest to, że mogą one spowodować, iż dwa podmioty znajdujące się w identycznej sytuacji faktycznej będą traktowane odmiennie, gdy jeden z nich uzyska korzystną, ale sprzeczną z prawem interpretację. Przywrócenie równości jest oczywiście możliwe poprzez zmianę tej interpretacji. Jednak mechanizm ten jest trudny do wykorzystania z praktycznego punktu widzenia, gdyż wymaga starannego monitorowania treści interpretacji indywidualnych. W polskich realiach ${ }^{42}$ jest to działanie bardzo trudne organizacyjnie oraz kosztowne.

Danie prymatu interpretacjom ogólnym może pociągać za sobą także pewne korzyści organizacyjne i finansowe dla aparatu skarbowego. Otóż zmiana poglądu co do wykładni prawa (zwłaszcza - zmiana na niekorzyść jednostek) nie musi oznaczać konieczności zmiany licznych interpretacji indywidualnych. Wprowadzenie takiego rozwiązania na gruncie polskiego prawa podatkowego dałoby niebagatelne korzyści, jeżeli wziąć pod uwagę liczbę interpretacji indywidualnych wydawanych w Polsce i to, że ich zmiana polega na wydaniu nowej interpretacji, która może być przedmiotem skargi do sądu administracyjnego ${ }^{43}$.

\section{Podsumowanie}

Przeprowadzona powyżej analiza regulacji oraz praktyki stosowania prawa pozwala stwierdzić brak „sztywnej” hierarchizacji interpretacji prawa podatkowego. Hierarchizacja nie jest warunkiem koniecznym istnienia efektywnego systemu interpretacji prawa. Jest to więc sytuacja z gruntu odmienna niż ta dotycząca obowiązywania przepisów prawa, które muszą z natury rzeczy być w jakiś sposób hierarchizowane.

$\mathrm{Na}$ gruncie prawa celnego można próbować sformułować pewną hierarchię interpretacji, chociażby w zakresie klasyfikacji taryfowej. Można więc przyjąć, że noty Komisji i WCO w pewnym sensie stoją hierarchicznie wyżej niż WIT (ale tylko wydane uprzednio), a noty WCO stoją hierarchicznie wyżej niż noty Komisji. Trzeba jednak mieć na względzie to, że jednocześnie WIT są wiążące, natomiast noty i opnie WCO oraz noty Komisji - niewiążące. Paradoks polega na tym, że instrument stojący hierarchicznie „wyżej” może być odrzucony przez organ stosujący prawo. W efekcie do powyższej hierarchizacji należy podchodzić dość ostrożnie.

${ }^{42}$ W 2009 r. wydano ok. 30 tys. indywidualnych interpretacji - cyt. za: Ministerstwo Finansów, Zatożenia do projektu ustawy o zmianie ustawy - Ordynacja podatkowa oraz o zmianie ustawy o podatku dochodowym od osób fizycznych (projekt z dnia 10 lutego 2011 r.), s. 8.

${ }_{43}$ Średni koszt wydania jednej interpretacji indywidualnej wynosił w 2009 r. 1072 zł - cyt. za: Ministerstwo Finansów, Założenia do projektu ustawy..., s. 9. 